\title{
Lokalne bieguny wzrostu w Polsce (według budżetów gmin i przedsiębiorczości prywatnej)
}

Przemiany ustrojowe zapoczątkowane w 1989 roku spowodowały w Polsce dynamiczny rozwój prywatnej przedsiębiorczości, w tym głównie małych firm borykających sie ciagle $\mathrm{z}$ wieloma trudnościami. W połowie ostatniej dekady XX wieku przekroczona jednak została symboliczna granica tej prywatyzacji, za jaką można uważać jej ponad $50 \%$ udział w ogólnej strukturze zatrudnienia. Obecnie odsetek ten jest znacznie wyższy.

Oprócz dużych miast wojewódzkich i głównych aglomeracji, gdzie przedsiębiorczość prywatna znalazła dogodne warunki dla rozwoju, istnieje Polska gminna i powiatowa, w której zjawiska powyższe kształtują się niejednolicie. W jednych miejscach inicjatywa prywatna rozwija się dynamicznie i ośrodki te można zaliczyć do "lokalnych biegunów wzrostu”, w innych zaś występuje stagnacja i niemoc działania. Powstaje pytanie, jaki jest przestrzenny obraz tej prywatyzacji i natężenie występujących zjawisk?

Drugim powodem podjęcia niniejszych badań jest renesans w nauce europejskiej zmodyfikowanej "teorii polaryzacji” (Théorie du Développement Régional Polarisé), a ściślej biorąc różnych jej odmian. W klasycznym dziś studium F. Perroux (1955, s. 309) twierdził, że: "Wzrost nie uwidacznia się wszędzie jednocześnie; przejawia się on ze zmienną intensywnością w postaci punktów lub biegunów wzrostu; rozchodzi się różnymi kanałami i ze zmiennymi skutkami końcowymi dla całości gospodarki”. F. Perroux wprowadził pojęcie "przestrzeni spolaryzowanej", będącej wynikiem działania określonego bieguna wzrostu,

z którego emanują siły odśrodkowe i dośrodkowe, powodujące wykształcenie się sfery gospodarczej, będącej obszarem jego oddziaływania.

Według J. Paelincka (1965, s. 47) teoria powyższa formułuje możliwości wzrostu regionów, a jej znaczenie polega przede wszystkim na ukazaniu warunków, w jakich może nastąpić ich przyśpieszony rozwój. "Koncepcję biegunów wzrostu” adoptował dla potrzeb ekonomiki regionalnej J. Boudeville (1972), co w efekcie zaowocowało różnym jej nazewnictwem, np. koncepcja biegunów wzrostu (lub rozwoju), ośrodków wzrostu lub rozwoju spolaryzowanego. 
Tablica 1. Konstrukcja badawcza problemu "Lokalne bieguny wzrostu przedsiębiorczości prywatnej” (Projekt Badawczy KBN nr 1HO2C O13 15)

\begin{tabular}{|c|c|c|c|c|}
\hline \multirow{2}{*}{ Część } & \multirow{2}{*}{ Problematyka } & \multicolumn{3}{|c|}{ Postępowanie badawcze } \\
\hline & & Ogólna charakterystyka & Analiza & Synteza \\
\hline I. & $\begin{array}{l}\text { Polityka in- } \\
\text { nowacyjna } \\
\text { w krajach } \\
\text { gospodarczo } \\
\text { rozwiniętych }\end{array}$ & $\begin{array}{l}\text { 1. Światowe centra } \\
\text { innowacyjne } \\
\text { 1.1. Stany Zjednoczone } \\
\text { 1.2. Daleki Wschód } \\
\text { 1.3. Bliski Wschód } \\
\text { 1.4. Unia Europejska }\end{array}$ & $\begin{array}{l}\text { 2. Konstrukcja } \\
\text { modelu "Terza } \\
\text { Italia" } \\
\text { 2.1. Identyfikacja } \\
\text { cech } \\
\text { 2.2. } \begin{array}{l}\text { Modele duński } \\
\text { i holenderski }\end{array}\end{array}$ & $\begin{array}{l}\text { 3. Uniwersalny model } \\
\text { "lidera dla Polski" } \\
\text { 3.1. Rynek finansowy } \\
\text { 3.2. Charakter własności } \\
\text { 3.3. Opłaty obowiązkowe } \\
\text { 3.4. Unifikacja modelu } \\
\text { "lidera" }\end{array}$ \\
\hline II. & $\begin{array}{l}\text { Rola i zna- } \\
\text { cze-nie ma- } \\
\text { tych } \\
\text { i średnich } \\
\text { przedsię- } \\
\text { biorstw } \\
\text { w gospodarce }\end{array}$ & $\begin{array}{l}\text { 1. Małe i średnie } \\
\text { przedsiębiorstwa } \\
\text { w gospodarce } \\
\text { 1.1. Stany Zjednoczone } \\
\text { 1.2. Unia Europejska } \\
\text { 2. Kraje postsocjali- } \\
\text { styczne } \\
\text { 2.1. Dotychczasowy } \\
\text { rozwój } \\
\text { 2.2. Wspieranie } \\
\text { 2.3. Pomoc UE }\end{array}$ & $\begin{array}{l}\text { 3. Stan i rozwój ma- } \\
\text { lych i średnich } \\
\text { przedsiębiorstw } \\
\text { w Polsce } \\
\text { 3.1. Przedsiębiorstwa } \\
\text { i pracujący } \\
\text { 3.2. Układ woje- } \\
\text { wódzki } \\
\text { 3.3. Układ gminny } \\
\text { 3.4. Uwagi ogólne }\end{array}$ & 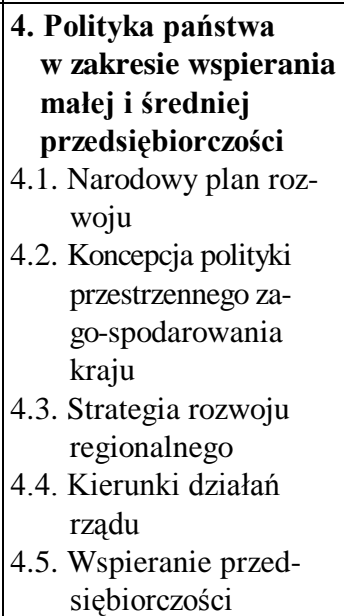 \\
\hline III. & $\begin{array}{l}\text { Analiza sytu- } \\
\text { a-cji finanso- } \\
\text { wej i atrak- } \\
\text { cyjno-ści go- } \\
\text { spodarczej } \\
\text { gmin } \\
\text { w Polsce }\end{array}$ & $\begin{array}{l}\text { 1. Charakterystyka } \\
\text { sytuacji finansowej } \\
\text { gmin w Polsce } \\
\text { 1.2. Dochody gmin } \\
\text { 1.3. Wydatki gmin } \\
\text { 1.4. Analiza budżetów } \\
\text { gmin metodą } \\
\text { J.W. Weavera }\end{array}$ & $\begin{array}{l}\text { 5. Atrakcyjność } \\
\text { gospodarcza gmin } \\
\text { 5.1. Dotychczasowe } \\
\text { badania } \\
\text { 5.2. } \text { Bezrobocie } \\
\text { a sytuacja } \\
\text { gospodarcza }\end{array}$ & $\begin{array}{l}\text { 6. Metoda "wspólczyn- } \\
\text { ników syntetycznych } \\
\text { cech" } \\
\text { 6.1. Postępowanie } \\
\text { badawcze } \\
\text { 6.2. Interpretacja } \\
\text { wyników }\end{array}$ \\
\hline IV. & $\begin{array}{l}\text { Lokalne bie- } \\
\text { guny wzrostu } \\
\text { przedsiębior- } \\
\text { czości pry- } \\
\text { watnej }\end{array}$ & $\begin{array}{l}\text { 1. Środowiska regio- } \\
\text { nalne lokalnych bie- } \\
\text { gunów wzrostu } \\
\text { 1.1. Założenia metodyczne } \\
\text { 1.2. Lokalne bieguny } \\
\quad \text { wzrostu w ujęciu wo- } \\
\text { jewódzkim }\end{array}$ & $\begin{array}{l}\text { 2. Weryfikacja uzy- } \\
\text { skanych wyników } \\
\text { 2.1. Metoda "wspó1- } \\
\text { czynników syn- } \\
\text { tetycznych..." } \\
\text { a dotychczasowe } \\
\text { badania } \\
\text { 2.2. Metoda "wspó1- } \\
\text { czynników syn- } \\
\text { tetycznych..." } \\
\text { a rzeczywistość }\end{array}$ & $\begin{array}{l}\text { 3. Lokalne bieguny } \\
\text { wzrostu } \\
\text { 3.1. Typologia } \\
\text { 3.2. Wyniki badań } \\
\text { w świetle założeń } \\
\text { teoretycznych } \\
\text { 3.3. Model "lidera" } \\
\text { w polskiej rzeczy- } \\
\text { wistości }\end{array}$ \\
\hline
\end{tabular}


Oprac. J. Dębski

- część pracy przedstawiona w niniejszym artykule

\section{ZAKRES TERYTORIALNY I PODMIOTOWY}

Przeprowadzone badania (finansowane przez KBN Projekt Badawczy nr 1 HO2C O13 15, wykonywane w WSzFiZ w Białymstoku) objęły całą Polskę w ujęciu gminnym (gminy miejskie, miejsko-wiejskie i wiejskie), odwołując się w przypadkach niezbędnych również do poszczególnych miejscowości. Zgodnie z tematem pracy, który dotyczy "lokalnych biegunów wzrostu", ograniczone zostały badania miast wojewódzkich wraz z obszarami przylegającymi do nich bezpośrednio. Powstało jednak pytanie, jak zdefiniować pojęcie lokalności? Według A. Kuklińskiego (1986) termin ten obejmuje zjawiska przestrzenne domykające się bilansowo lub decyzyjnie

w skali lokalnej. O domknięciu bilansowym można mówić w wypadku lokalnych rynków pracy lub lokalnych rynków towarowych, natomiast o domknięciu decyzyjnym, gdy w omawianej skali przestrzennej istnieją osoby, instytucje i przedsiębiorstwa, które podejmują względnie samodzielne decyzje kształtujące miejscową rzeczywistość. W. Kosiedowski (1986) uważa, że termin "lokalny" znaczy to samo co miejscowy, charakterystyczny dla danego miejsca i nie wychodzacy poza określone przedziały. K. Herbat (1986) twierdzi, iż uzasadnione wydaje się odniesienie pojęcia lokalności do skali pojedynczej jednostki osadniczej (dzielnicy, miasta, sołectwa, wsi) i jej wewnętrznej struktury (Gołembska 1990, s. 226-227).

Należy dodać, że w Polsce, zgodnie z Ustawą z dnia 7 lipca 1994 roku o zagospodarowaniu przestrzennym (Dz. Ust. 1999, nr 15, poz. 139 ze zmianami), planowanie przestrzenne pozostało jedynie na poziomie lokalnym, a "miejscowy plan zagospodarowania przestrzennego" jest przepisem gminnym (Art. 7). Wynika z tego, że ustawodawca traktuje pojęcia "lokalny" i "miejscowy" jako synonimy odnoszące się do jednostki administracyjnej - gminy". To właśnie na jej terenie można mówić o domknięciu bilansowym i decyzyjnym, o którym wspominał A. Kukliński. Innymi słowy ustawodawca wyraził ideę, że podmiotami władania publiczno-prawnego są na terenie gminy przede wszystkim jednostki samorządu terytorialnego. Tak więc "lokalnymi biegunami wzrostu" mogą być gminy miejskie, w tym również miasta pełniące funkcje ośrodków powiatowych, oraz gminy miejsko-wiejskie i wiejskie.

Zakres podmiotowy dotyczy przedsiębiorczości prywatnej w ujęciu gminnym według liczby i charakteru zakładów oraz zatrudnionych. Już w 1996 roku było w Polsce 2379,9 tys. przedsiębiorstw, z czego 2311,9 tys. stanowiły firmy prywatne, a tylko 67,9 tys. przedsiębiorstwa państwowe. Dla porównania, we Francji było w tym czasie 2085 tys., a w Niemczech 3440 tys. firm.

Głównym obiektem zainteresowania badawczego w pracy są małe i średnie przedsiębiorstwa, produkcyjne i nieprodukcyjne, które stanowią 99,0\% wszystkich zarejestrowanych jednostek tego typu w Polsce. Według Ministerstwa Gospodarki przyjmuje się następująca definicję małych i średnich firm (zgodnie z projektem ustawy "Prawo działalności gospodarczej”):

\footnotetext{
* Podobnie jest w większości krajów Unii Europejskiej. We Francji “plan d'occupation des sols" - dotyczy skali 1:2000 dla miasta i 1:10000 dla gminy wiejskiej; w Holandii - plan lokalny użytkowania terenu (Bestemmingsplan) i odnowy miasta (Stadtsvermieuwingsplan) dotyczy skali 1:500 i 1:10000; w Niemczech - plan użytkowania terenów (Flachennuzungsplan) i plan zabudowy (Bebaungsplan) dotyczy skali 1:10000 i 1:1000 (lub 1:500).
} 
— Za małego przedsiębiorcę uważa się firmę, w której w poprzednim roku obrotowym zatrudniano (średnio rocznie) poniżej 50 pracowników oraz gdzie osiagnięty przychód netto ze sprzedaży towarów, wyrobów, usług i operacji finansowych nie przekroczył równowartości (w zł) 7 mln euro lub gdy suma aktywów bilansu firmy (sporządzonego na koniec roku obrotowego) nie przekroczyła równowartości (w zł) 5 mln euro.

- Za średniego przedsiębiorcę uważa się firmę, w której w poprzednim roku obrotowym zatrudniano przeciętnie rocznie poniżej 250 pracowników oraz gdy przychód netto nie przekroczył (w zł) równowartości $40 \mathrm{mln}$ euro lub gdy suma aktywów jej bilansu nie przekroczyła (w zł) równowartości 27 mln euro.

Charakterystyka gmin - traktowanych jako podstawowe jednostki przestrzenne wymagała, oprócz oceny ich ogólnej sytuacji społeczno-ekonomicznej, przedstawienia także struktury budżetów gminnych. Analizowane były dochody własne gmin, w tym podatki: od osób fizycznych i prawnych, rolny, od nieruchomości, od środków transportu, oraz inne dochody własne i opłaty lokalne. Poza tym zbadano wielkość i rozmieszczenie subwencji oraz dotacje z budżetu państwa i ze źródeł pozabudżetowych. Wydatki gmin rozpatrywane były pod kątem inwestowania w infrastrukturę techniczną, oświatę i gospodarkę mieszkaniową. W niniejszym opracowaniu uwzględnione zostały również inicjatywy lokalne i różnorodne formy wspierania przedsiębiorczości. Można tu wymienić: centra wspierania biznesu, inkubatory przedsiębiorczości, agencje rozwoju regionalnego, izby gospodarcze

i ośrodki informacji, parki przemysłowe itp.

\section{POSTĘPOWANIE BADAWCZE}

Konstrukcja metodyczna “wskaźników syntetycznych”, przy pomocy której przeprowadzono wydzielenie centralnych i lokalnych ośrodków aktywności gospodarczej, nawiązuje do metody odległości taksonomicznej od wzorca (Swianiewicz, Dziemianowicz 1998).

Główną miarą stosowaną w tej metodzie są znormalizowane wartości analizowanych cech parametrów, obliczone według wzoru:

$$
\mathrm{Z}=\frac{\mathrm{X}-\overline{\mathrm{X}}}{\mathrm{S}}
$$

gdzie:

$$
\begin{aligned}
& \mathrm{Z} \text { - wartość znormalizowana } \\
& \mathrm{X} \text { - wartość analizowanego parametru } \\
& \overline{\mathrm{X}} \text { - średnia analizowanego parametru } \\
& \mathrm{S} \text { - odchylenie standardowe }
\end{aligned}
$$

Obliczenia zostały przeprowadzone dla wybranych cech 19 parametrów przedstawionych $\mathrm{w}$ tablicy 2 . Następnym etapem było stworzenie subagregatów skupiających kilka wybranych cech o podobnej tematyce. Subagregaty połączono w jeden wskaźnik syntetyczny, zostały one utworzone poprzez obliczenie średniej z wartości znormalizowanych dla poszczególnych cech. Wskaźnik syntetyczny zaś skonstruowano wykorzystując średnią 
wagową (wagi były związane z liczbą poszczególnych cech wchodzących w skład danego subagregatu). Taka procedura pozwoliła na przedstawienie cech, subagregatów i wreszcie wskaźnika syntetycznego w jednolitym zakresie wartości odniesionym do średniej i odchylenia standardowego. Wartość zero oznaczała zawsze, że dany obiekt posiada średnie wartości danej cechy, subagregatu czy wskaźnika syntetycznego; wartość jeden, że posiada wartości powyżej średniej o jedno odchylenie standardowe, a minus jeden - odwrotnie.

Tablica 2. Objaśnienia składowych subagregatów

dla wskaźnika syntetycznego bezwzględnego i względnego

Analizowane parametry

Wskaźnik syntetyczny
Subagregaty

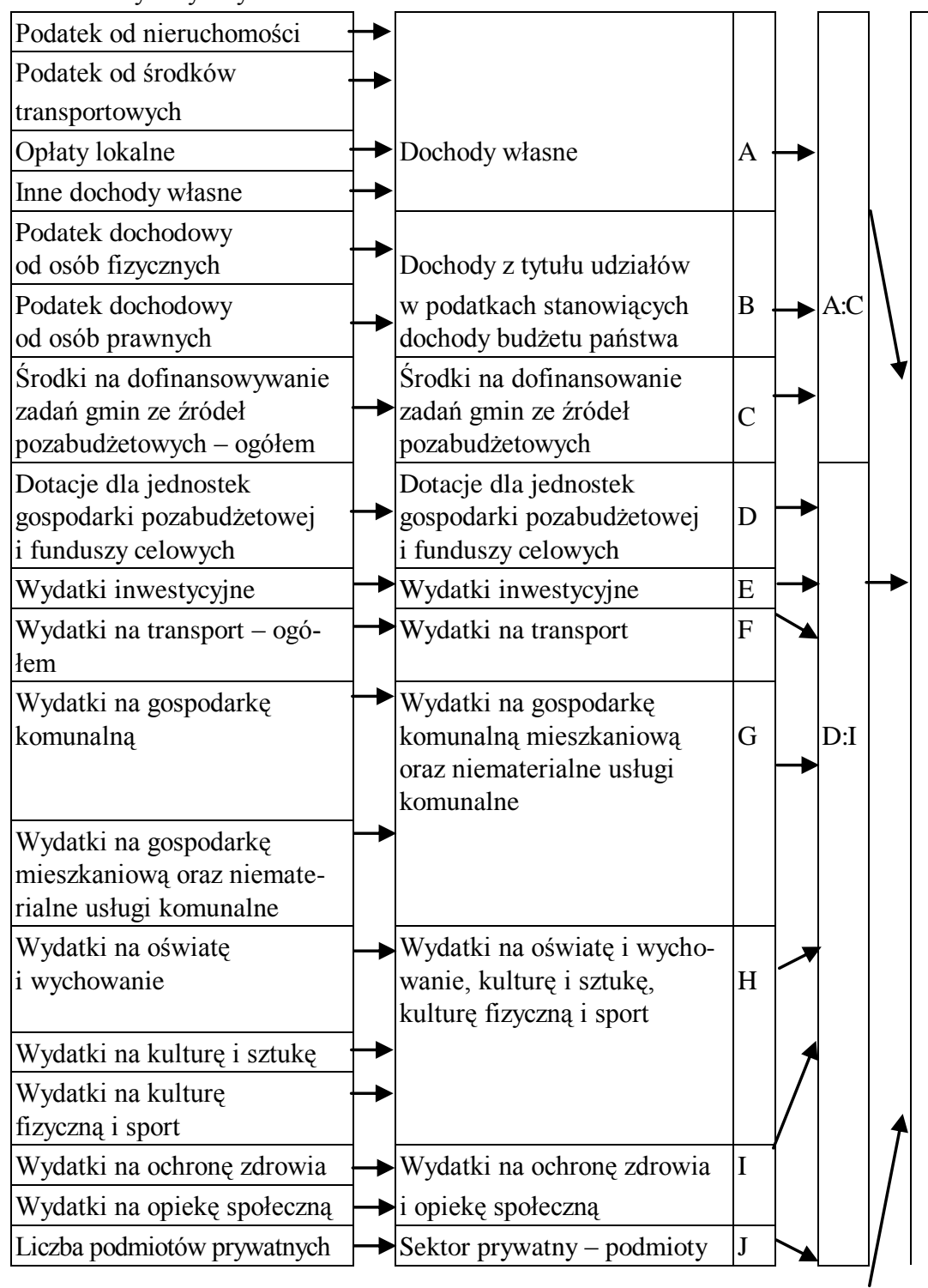


Liczba zatrudnionych

w sektorze prywatnym

Sektor prywatny - zatrudnieni $\mathrm{K}$

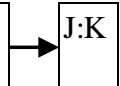

Oprac. J. Dębski

Subagregat A:C wyraża cechy zwiazane $\mathrm{z}$ dochodami gmin, subagregat D:I - cechy związane $\mathrm{z}$ wydatkami gmin, zaś subagregat $\mathrm{J}: \mathrm{K}$ - podmioty i zatrudnionych $\mathrm{w}$ sektorze prywatnym. Obliczenia przeprowadzono w dwóch wersjach: bezwzględnej, która wyrażała potencjał danej gminy, i względnej, która oddawała cechy strukturalne. Subagregaty dochodów i wydatków gmin odniesione zostały na jednego mieszkańca, zaś subagregat podmiotów i zatrudnionych w sektorze prywatnym wyrażony został przez ich odsetek.

Tablica 3. Model badawczy zastosowany w pracy

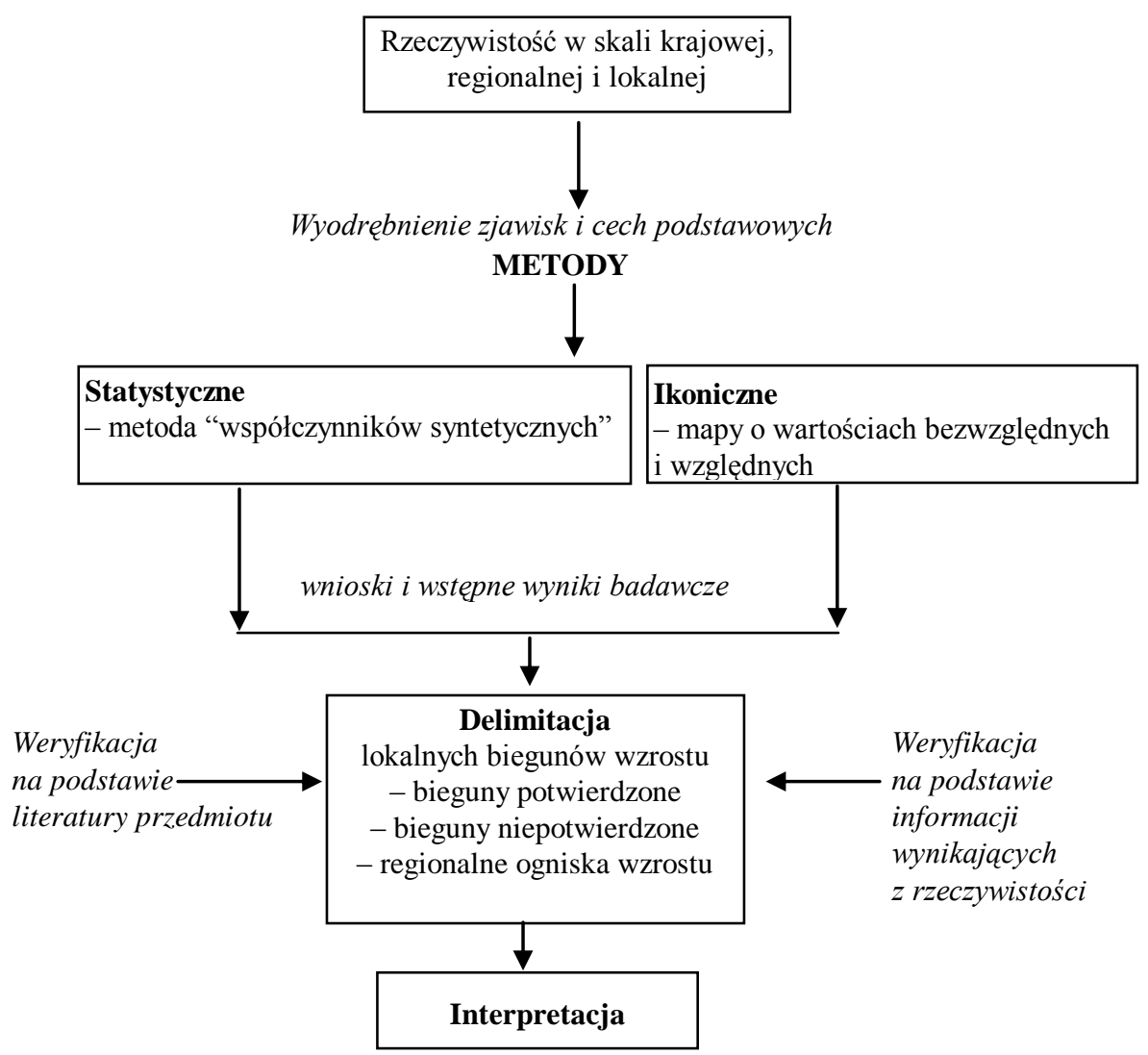

Oprac. J. Dębski 
Subagregaty obliczone zostały według wzoru:

$$
\mathrm{S}=\frac{\sum_{\mathrm{i}=1}^{\mathrm{n} Z \mathrm{Zi}}}{\mathrm{n}}
$$

gdzie:

$$
\begin{aligned}
& \mathrm{S} \text { - wartość subagreatu } \\
& \mathrm{Z} \text { - wartość znormalizowana cechy i } \\
& \mathrm{n} \text { - liczba cech wchodzących w skład subagregatu }
\end{aligned}
$$

Następny etap polegał na testowaniu różnych wag subagregatów przy obliczaniu wskaź-nika syntetycznego, a w kolejnych wariantach nadano im następujące wagi:

\begin{tabular}{|l|c|c|c|}
\hline \multirow{2}{*}{} & \multicolumn{3}{|c|}{ Wagi subagregatów } \\
\cline { 2 - 4 } & A:C & D:I & J:K \\
\hline Wariant 0 & $3 / 11$ & $6 / 11$ & $2 / 11$ \\
\hline Wariant I & $1 / 3$ & $1 / 3$ & $1 / 3$ \\
\hline Wariant II & $1 / 4$ & $1 / 4$ & $2 / 4$ \\
\hline Wariant III & $1 / 8$ & $1 / 8$ & $6 / 8$ \\
\hline
\end{tabular}

Obliczono też wskaźnik syntetyczny (całościowy) - A:K - poprzez średnie ważone, zachowując przy tym wymagania tworzenia uniwersalnych miar znormalizowanych. Zsumowane wagi subagregatów w poszczególnych wariantach wynosiły zawsze jeden.

Wskaźnik syntetyczny obliczony został według wzoru:

$$
\mathrm{W}=\sum^{\mathrm{n}} \mathrm{cSi}
$$

gdzie:

$$
\begin{aligned}
& \text { W - wartość wskaźnika syntetycznego } \\
& \mathrm{S} \text { - wartość subagregatu i } \\
& \text { c - waga subagregatu i }
\end{aligned}
$$

W wariancie 0 , jak wyjaśniono powyżej, wagi subagregatów uzależnione były od liczby cech składających się na dany subagregat. Wskaźnik syntetyczny zawierał w sobie jednakową informację o wszystkich cechach. W wariancie I subagregaty otrzymały równomierne wagi. W kolejnych dwóch wariantach (II i III) uznano, że waga subagregatu ujmującego podmioty i zatrudnionych w sektorze prywatnym jest najważniejsza i powinna być najwyższa ze względu na cele przeprowadzonej analizy. W związku z tym jego wagę zwiększono odpowiednio do $2 / 4$ i 6/8. Subagregat ten wyjaśniał więc 50\% i 75\% zmienności wskaźnika syntetycznego.

W tabelach zestawiono kolejność gmin według najwyższych wskaźników syntetycznych $\mathrm{w}$ wersji bezwzględnej $\mathrm{w}$ ujęciu wojewódzkim. W zestawieniach tabelarycznych przedstawiono wartości znormalizowane wszystkich cech, obliczone subagregaty i wskaź- 
niki syntetyczne A:K, zgodnie z którymi posortowano gminy oraz pozycje zajmowane przez daną jednostkę w województwie według określonego wariantu. Warianty I, II i III opisane są poprzez wartość kolejnych współczynników wagowych dla subagregatów.

Tabela 1 


\section{INTERPRETACJA WYNIKÓW}

Jak już wcześniej podano, analizowane zbiory danych zostały podzielone na dwie grupy według współczynników syntetycznych - bezwzględnego i względnego (w przeliczeniu na 1 mieszkańca danej gminy).

Współczynnik syntetyczny bezwzględny charakteryzuje się dużym zróżnicowaniem w układzie wojewódzkim oraz dużą wagą obiektów o maksymalnych wartościach. Innymi słowy występuje znaczna koncentracja wartości agregatów A:K we wszystkich prezentowanych wariantach: 0, I, II i III. Współczynnik syntetyczny wyższy od 1,5 odchylenia od wzorca występuje tylko w przypadku 42 miast największych. Należy dodać, że do powyższej zbiorowości zaliczane były te jednostki, jeżeli w jednym tylko wariancie wystąpiło przekroczone 1,5 wartości odchylenia od średniej. W pozostałych gminach występuje gwałtowny spadek wartości omawianego współczynnika we wszystkich badanych wariantach. Tabela 1 wskazuje na główne gminy miejskie wybijające się znacznie z analizowanej zbiorowości (2489 jednostek). Pierwsze miejsce zajmuje Warszawa-Centrum o wartościach współczynnika syntetycznego wyższych od wzorca, rosnących w miarę przechodzenia od wariantu 0 do wariantu III. Świadczy to o dużym znaczeniu subagregatu J:K ujmującego

w najwyższym (w stosunku do I i II) stopniu podmioty i zatrudnionych w sektorze prywatnym, ze szczególnym uwzględnieniem małych i średnich przedsiębiorstw. Na drugim miejscu w Polsce pod względem wartości tego współczynnika znajduje się gmina miejska Wrocław, gdzie sytuacja jest odmienna. Dominuje tutaj pod względem wartości wariant 0 , zależny - jak już było podane - od jednakowej liczby cech. Na trzecim miejscu znajduje się Poznań z wielką przewagą wskaźnika syntetycznego w wariancie III.

Zestawienie zawarte w tabeli 1 wskazuje na:

- bardzo duże różnice w wartości prezentowanego współczynnika w tak niedużej grupie, jaką jest 20 powyższych gmin miejskich. Różnice te wynoszą 1:10;

- w grupie tej znalazły się prawie wszystkie stolice wojewódzkie, z wyjątkiem Gorzowa Wielkopolskiego i Zielonej Góry;

- najwyższe wartości tego współczynnika dotyczą: Warszawy-Centrum, Wrocławia, Poznania, Łodzi i Krakowa (powyżej 10,000);

- średnie wartości $(5,000-8,800)$ cechują kolejne miasta: Gdańsk, Katowice, Szczecin, Bydgoszcz i Częstochowę; 
- niższe wartości w grupie 20 gmin (ale wysokie w skali 2489 jednostek) charakteryzują: Lublin, Toruń, Opole, Gdynię, Rzeszów, Białystok, Kielce, Bielsko-Białą, Gliwice i Olsztyn (wartości 2,700-4,400);

- z pozostałych 22 miast z grupy 42 o wartościach współczynnika syntetycznego wyższego od 1,5 (tabela 1) ma wskaźnik od 1/20 do 1/10 wartości podanej dla jednej gminy Warszawa-Centrum. A nie jest to przecież całe miasto stołeczne tylko jego główna gmina!

Tabela 2. Dwadzieścia gmin o najwyższym w Polsce współczynniku syntetycznym (bezwzględnym)

\begin{tabular}{|c|c|c|c|c|c|}
\hline \multirow{2}{*}{$\begin{array}{l}\text { Kolejność } \\
\text { w Polsce }\end{array}$} & \multirow[b]{2}{*}{ Gminy miejskie } & \multicolumn{4}{|c|}{ Agregat A:K } \\
\hline & & Wariant 0 & $\begin{array}{c}\text { Wariant I } \\
(1 / 3 * 3)\end{array}$ & $\begin{array}{c}\text { Wariant II } \\
(1 / 4 * 2+1 / 2)\end{array}$ & $\begin{array}{l}\text { Wariant III } \\
1 / 8 * 2+3 / 4) \\
\end{array}$ \\
\hline 1. & Warszawa-Centrum & 22,544 & 25,124 & 27,628 & 31,384 \\
\hline 2. & Wrocław & 14,864 & 14,266 & 13,385 & 12,063 \\
\hline 3. & Poznań & 12,085 & 12,119 & 12,605 & 13,335 \\
\hline 4. & Łódź & 12,429 & 12,438 & 12,522 & 12,649 \\
\hline 5. & Kraków & 9,667 & 10,358 & 11,257 & 12,606 \\
\hline 6. & Gdańsk & 8,789 & 8,562 & 8,438 & 8,252 \\
\hline 7. & Katowice & 6,845 & 6,992 & 7,514 & 8,296 \\
\hline 8. & Szczecin & 6,439 & 6,327 & 6,545 & 6,871 \\
\hline 9. & Bydgoszcz & 5,172 & 5,010 & 5,175 & 5,423 \\
\hline 10. & Częstochowa & 5,621 & 4,691 & 4,510 & 4,238 \\
\hline 11. & Lubin & 4,027 & 4,132 & 4,270 & 4,478 \\
\hline 12. & Toruń & 3,646 & 3,626 & 3,594 & 3,546 \\
\hline 13. & Opole & 3,833 & 4,011 & 3,651 & 3,111 \\
\hline 14. & Gdynia & 3,304 & 3,411 & 3,651 & 4,013 \\
\hline 15. & Rzeszów & 3,209 & 3,014 & 3,056 & 3,119 \\
\hline 16. & Białystok & 3,319 & 3,326 & 3,410 & 3,535 \\
\hline 17. & Kielce & 2,750 & 2,839 & 3,027 & 3,422 \\
\hline 18. & Bielsko-Biała & 2,853 & 2,976 & 3,211 & 3,564 \\
\hline 19. & Gliwice & 2,612 & 2,777 & 2,961 & 3,237 \\
\hline 20. & Olsztyn & 2,826 & 2,732 & 2,811 & 2,930 \\
\hline
\end{tabular}

Oprac. J. Dębski

Rachunek korelacji opracowany dla całej zbiorowości gmin wskazuje na wysokie wartości pomiędzy analizowanymi wariantami.

Współczynnik korelacji pomiędzy wariantami współczynnika syntetycznego (bezwzględnego)

\begin{tabular}{|l|c|c|c|}
\hline & $\begin{array}{c}\text { Agregat A:K } \\
\text { Wariant I } \\
(1 / 3 * 3)\end{array}$ & $\begin{array}{c}\text { Agregat A:K } \\
\text { Wariant II } \\
(1 / 4 * 2+1 / 2)\end{array}$ & $\begin{array}{c}\text { Agregat A:K } \\
\text { Wariant III } \\
(1 / 8 * 2+3 / 4)\end{array}$ \\
\hline $\begin{array}{l}\text { Agregat A:K } \\
\text { Wariant 0 }\end{array}$ & 0,997 & 0,991 & 0,976 \\
\hline
\end{tabular}




\begin{tabular}{|l|c|c|c|}
\hline $\begin{array}{l}\text { Agregat A:K } \\
\text { Wariant I } \\
(1 / 3 * 3)\end{array}$ & $\mathrm{X}$ & 0,998 & \\
\hline $\begin{array}{l}\text { Agregat A:K } \\
\text { Wariant II } \\
(1 / 4 * 2+1 / 2)\end{array}$ & $\mathrm{X}$ & $\mathrm{X}$ & 0,988 \\
\hline
\end{tabular}

Najwyższy współczynnik korelacji występuje w przypadku wariantu I i II, wariantu 0 i I oraz II i III. W tym ostatnim przypadku waga subagregatu J:K jest najwyższa i wyjaśnia $50 \%$ i 74\% zmienności wskaźnika syntetycznego. Ze względu na wysoki współczynnik korelacji za reprezentatywny został uznany wariant II.

Tabela 3 
tabela 4 
Wokół wspomnianych wielkich miast tworzą się również rozległe obszary tej aktywności o niższych wskaźnikach niż w centrum, ale wyraźnie wyróżniające się z otoczenia. Mowa tu o aglomeracji warszawskiej, konurbacji katowickiej, aglomeracji gdańskiej, poznańskiej i szczecińskiej oraz w mniejszym stopniu krakowskiej, łódzkiej i wrocławskiej. Gminy otaczające te trzy ostatnie miasta nie tworzą już tak wyraźnych układów koncentrycznych.

Ogólnie biorąc gminy o wyższych wartościach współczynnika syntetycznego (bezwzględnego) układają się szerokim pasem południowo-zachodnim i zachodnim. W pozostałych częściach Polski tworzą większe wyspy wokół dużych miast oraz lokalne zgrupowania gmin miejskich i miejsko-wiejskich.

Współczynnik syntetyczny względny prezentowany jest w dwóch uzupełniających się tabelach (tab. 3 i 4 ). Wartości tego współczynnika, wyższe od 1,5 odchylenia od średniej, dotyczą 111 gmin: 9 miejskich, 9 miejsko-wiejskich i 93 wiejskich. Współczynnik względny, w przeciwieństwie do poprzedniego, przedstawia lokalne bieguny wzrostu gospodarczego. W województwie dolnośląskim znajduje się 13 takich ośrodków, kujawsko-po-morskim -5 , lubelskim -8 , lubuskim -11 , łódzkim -11 , małopolskim -4 , mazowieckim -7 , podkarpackim -5 , podlaskim -4 , pomorskim -10 , śląskim -4 , świętokrzyskim -2 , warmińsko-mazurskim -3 , wielkopolskim - 11 i zachodniopomorskim 16.

W grupie 111 analizowanych jednostek o współczynniku syntetycznym (względnym) wyższym od 1,5 odchylenia od wzorca w co najmniej jednym ujęciu wariantowym wyróżniają się następujące gminy:

- Grupa gmin o wysokich wartościach (powyżej 1,5) dla wszystkich 4 wariantów. Są to: Jerzmanowa i Głogów (02) ${ }^{* *}$, Łęknica, Lubniewice i Gozdnica (08), Nowosada i Kleszczów (10), Podkowa Leśna (14), Krynica Morska (22), Płoskinia (28), Kleszczewo (30), Kobylanka, Ustronie Morskie, Stepnica, Rewal, Dobra Szczecińska i Mielno (32). Ponieważ 17 powyższych gmin wyróżnia się we wszystkich wariantach w różnym stopniu wyrażonych (A:C, D:I, J:K) w skali całej Polski, można je określić jako główne lokalne ośrodki aktywności gospodarczej;

\footnotetext{
** Podobnie jak poprzednio, dla uproszczenia podano jedynie numery statystyczne województw: (02) dolnośląskie, (04) kujawsko-pomorskie, (06) lubelskie, (08) lubuskie, (10) łódzkie, (12) małopolskie, (14) mazowieckie, (16) opolskie, (18) podkarpackie, (20) podlaskie, (22) pomorskie, (24) śląskie, (26) świętokrzyskie, (28) warmińsko-mazurskie, (30) wielkopolskie, (32) zachodniopomorskie.
} 
- Grupa gmin o dużych wartościach współczynnika syntetycznego (powyżej 1,5) dla 3 wariantów I, II, III. Są to następujące gminy: Nieszawa i Wielka Nieszawka (04), Słońsk i Przewóz (08), Budziszewice (10), Słupno (14), Tyrawa Wołoska i Lutowiska (18), Łeba (22), Jejkowice (24), Ińsko (32). Do grupy tej należy zaliczyć Puchaczów (06) i Krupski Młyn (24) o dużych wartościach dla powiatów 0, I i II i niskich dla wariantu III. Te dwie ostatnie jednostki samorządowe wykazują się znacznym uprzemysłowieniem, ale o niewielkim udziale prywatnych małych i średnich firm. Cała powyższa grupa liczy 13 gmin.

- Grupa o dużych wartościach współczynnika syntetycznego (powyżej 1,5) dla 2 wariantów II i III (dominacja subagregatu J:K wyjaśniającego 50\% i 75\% jego zmienności). Są to następujące gminy: Żukowice i Kunice (02), Rossocz, Markuszów i Stoczek Łukowski (06), Wymiarki i Lipinki Łużyckie (08), Brok (14), Cisna i Czarna (18), Rutka-Tartak (20), Osiek

i Skórcz (22), Starcza (24), Kruklanki i Milejewo (28), Obrzycko, Powidz, Tarnówka, Wijewo, Domino i Kraszewice (30), Osina, Nowe Warpno (32). Do tej grupy zaliczają się również gminy o bardzo małych, a nawet minusowych wartościach współczynnika syntetycznego

w przypadku wariantu III i wysokich jego wartościach dla wariantów 0 i I. Są to jednostki samorządowe o dominującym przemyśle, ciężkim zlokalizowanym na swym terenie jak: Polkowice i Bogatynia (02) oraz Sitkówka-Nowiny (26), a także Tarnowo Podgórne położone na terenie aglomeracji poznańskiej o dobrze rozwiniętym przemyśle spożywczym i drzewnym. Z wyjątkiem tej ostatniej gminy, trzy poprzednio wymienione mają słabiej rozwinięty sektor przedsiębiorczości małej i średniej i duże dochody osiagane z podatku od nieruchomości (kopalnie miedzi, węgla brunatnego, zakłady cementowe). Stąd stosunkowo wysokie wskaźniki występują w 0 i I wariancie oraz niskie w III wariancie. Łącznie do tej kategorii zalicza się 28 gmin.

- Grupa gmin o średnich wartościach współczynnika syntetycznego (powyżej 1,5) dla jednego wariantu III (dominacja subagregatu J:K). Są to gminy w liczbie 53, które znalazły się w powyższej klasie ze względu na pewną aktywność gospodarczą w postaci rozwiniętej na swym terenie przedsiębiorczości prywatnej. W tej grupie występuje tylko jedno od tego odstęstwo - rolnicza gmina Łubnica (26) mająca najwyższe wartości współczynnika syntetycznego w wariantach 0 i I (subagregaty A:C i D:I)

Na 111 wyróżnionych gmin z 2489 analizowanych jednostek samorządowych wartości wyższe od 1,5 mają według poszczególnych wariantów:

\begin{tabular}{|c|c|c|c|c|}
\hline \multirow{2}{*}{$\begin{array}{c}\text { Współczynnik } \\
\text { syntetyczny } \\
>1,5\end{array}$} & Wariant 0 & $\begin{array}{l}\text { Wariant I } \\
(1 / 3 * 3)\end{array}$ & $\begin{array}{l}\text { Wariant II } \\
(1 / 4 * 2+1 / 2)\end{array}$ & $\begin{array}{l}\text { Wariant III } \\
(1 / 8 * 2+3 / 4)\end{array}$ \\
\cline { 2 - 5 } & \multicolumn{4}{|c|}{$\mathrm{L} \mathrm{i} \mathrm{c} \mathrm{z} \mathrm{b} \mathrm{a} \mathrm{g} \mathrm{m} \mathrm{i} \mathrm{n}$} \\
\cline { 2 - 5 } & 15 & 34 & 54 & 102 \\
\hline
\end{tabular}

Jak wynika z powyższego, stopniowe zwiększanie wagi subagregatu J:K przy jednoczesnym zmniejszaniu wag subagregatów A:C i D:I pozwoliło wydzielić więcej lokalnych ośrodków aktywności gospodarczej. Z tego względu wariant III został uznany za reprezentatywny dla wszystkich analizowanych gmin.

Współczynnik korelacji pomiędzy wariantami współczynnika syntetycznego (względnego)

\begin{tabular}{|l|c|c|c|}
\hline & $\begin{array}{c}\text { Agregat A:K } \\
\text { Wariant I } \\
(1 / 3 * 3)\end{array}$ & $\begin{array}{c}\text { Agregat A:K } \\
\text { Wariant II } \\
(1 / 4 * 2+1 / 2)\end{array}$ & $\begin{array}{c}\text { Agregat A:K } \\
\text { Wariant III } \\
(1 / 8 * 2+3 / 4)\end{array}$ \\
\hline Agregat A:K & 0,926 & 0,758 & 0,523 \\
\hline
\end{tabular}




\begin{tabular}{|l|c|c|c|}
\hline Wariant 0 & & & \\
\hline $\begin{array}{l}\text { Agregat A:K } \\
\text { Wariant I } \\
(1 / 3 * 3)\end{array}$ & $\mathrm{X}$ & 0,945 & 0,798 \\
\hline $\begin{array}{l}\text { Agregat A:K } \\
\begin{array}{l}\text { Wariant II } \\
(1 / 4 * 2+1 / 2)\end{array}\end{array}$ & $\mathrm{X}$ & $\mathrm{X}$ & 0,951 \\
\hline
\end{tabular}

Przeprowadzony rachunek korelacji wykazał, że najniższy współczynnik 0,523 występuje między wariantami 0 i III, co wynikało z zastosowania odmiennych ujęć metodycznych.

W pierwszym przypadku (zerowym) wagi subagregatów uzależnione były od liczby cech, w przypadku drugim i trzecim - wagi subagregatów ujmujących przedsiębiorczość prywatną zostały uznane za najważniejsze. Wysokie współczynniki korelacji wystąpiły pomiędzy:

- wariantami 0 i I - 0,926

- wariantami I i II - 0,945

- wariantami II i III - 0,951.

W Instytucie Badań nad Gospodarką Rynkową ustalono atrakcyjność miast - określoną przy pomocy syntetycznego wskaźnika składającego się z 10 podstawowych elementów, takich jak: chłonność rynku lokalnego, jakość rynku pracy, klimat społeczny, infrastruktura techniczna, infrastruktura otoczenia biznesu, koszty prowadzenia działalności gospodarczej, możliwości wypoczynkowe oraz aktywność marketingowa władz lokalnych. Łącznie wykonano 4 niezależne badania atrakcyjności inwestycyjnej: miast wojewódzkich, powiatów grodzkich, miast powiatowych i pozostałych ośrodków miejskich (Swianiewicz, Dziemianowicz 1999).

W rankingu opracowanym przez Centrum Badań Regionalnych, a dotyczącym 100 najlepszych gmin pod względem sumy inwestycji w latach 1997-1999 (w zł/ 1 osobę) uzyskiwany obraz jest dość podobny do przedstawionego w niniejszym opracowaniu. Mimo ciagłego pozostawiania w czołówce 100 najlepszych - dochody gmin, na terenie których znajdują się duże kopalnie, zmalały w ciągu ostatnich lat. Zmniejszyły się również zyski z targowisk przygranicznych uzyskiwane przez samorządy. Bazary nie są już tak atrakcyjne dla Niemców jak to było przed kilku laty. Jednocześnie gminy, w obrębie których zlokalizowane są znane kurorty nadmorskie, finansowo mają się dobrze. Dotyczy to szczególnie jednostek samorządowych położonych w województwie zachodniopomorskim, coraz bardziej w swoim rozwoju uwzględniających turystów z Niemiec, a szczególnie z pobliskiego Berlina. Położenie w sąsiedztwie polskich wielkich miast jest również czynnikiem sprzyjającym rozwojowi niektórych gmin. Wiele jednostek gminnych wymienionych w powyższym rankingu tworzy małe grupy sąsiedzkie, korzystające ze wspólnej infrastruktury technicznej, otoczenia biznesu itd.

Tabela 5. Pięćdziesiąt gmin o największych inwestycjach w skali kraju

\begin{tabular}{|c|c|c|c|c|c|c|c|}
\hline \multicolumn{4}{|c|}{ Według Centrum Badań Regionalnych } & \multicolumn{4}{|c|}{ Według J. Dębskiego } \\
\hline $\begin{array}{l}\text { Kolej- } \\
\text { ność }\end{array}$ & Gminy & $\begin{array}{l}\text { Nr wo- } \\
\text { jewódz- } \\
\text { twa }\end{array}$ & $\begin{array}{c}\text { Inwestycje } \\
\text { 1997-1999 } \\
\text { (ogółem w zł/ } \\
1 \text { osobę) }\end{array}$ & $\begin{array}{c}\text { Kolej- } \\
\text { ność }\end{array}$ & Gminy & $\begin{array}{l}\text { Nr woje- } \\
\text { wództwa }\end{array}$ & $\begin{array}{c}\text { Inwestycje } \\
1998 \text { r. } \\
\text { (ogółem w zł/ } \\
1 \text { osobę) }\end{array}$ \\
\hline 1. & Rewal $^{\mathrm{xx}}$ & 32 & 6130 & 1. & Kleszczów & 10 & 3710,0 \\
\hline 2. & Polkowice ${ }^{\mathrm{xx}}$ & 02 & 5197 & 2. & Rewal & 32 & 2483,8 \\
\hline
\end{tabular}


Lokalne bieguny wzrostu w Polsce...

\begin{tabular}{|c|c|c|c|c|c|c|c|}
\hline 3. & Łęknica ${ }^{\mathrm{xx}}$ & 08 & 4483 & 3. & $\begin{array}{l}\text { Dobra } \\
\text { (Szczecińska) }\end{array}$ & 32 & 2360,7 \\
\hline 4. & $\begin{array}{l}\text { Tarnowo } \\
\text { Podgórne }^{\mathrm{xxx}}\end{array}$ & 30 & 4457 & 4. & Polkowice & 02 & 2081,8 \\
\hline 5. & Kobierzyce $^{\mathrm{xx}}$ & 02 & 4330 & 5. & Łęknica & 08 & 1677,0 \\
\hline 6. & Bogatynia $^{\mathrm{xx}}$ & 02 & 4014 & 6. & \begin{tabular}{|l} 
Puchaczów \\
\end{tabular} & 06 & 1628,4 \\
\hline 7. & Puchaczów $^{\mathrm{xx}}$ & 06 & 3934 & 7. & Bogatynia & 02 & 1624,5 \\
\hline 8. & Mielno $^{\mathrm{xx}}$ & 32 & 3934 & 8. & Świnoujście & 32 & 1589,5 \\
\hline 9. & Leba $^{\mathrm{xx}}$ & 22 & 3700 & 9. & Bojszowy & 24 & 1409,1 \\
\hline 10. & Świnoujście ${ }^{\mathrm{xx}}$ & 32 & 3574 & 10. & Łeba & 22 & 1398,0 \\
\hline 11. & $\begin{array}{l}\text { Ustronie } \\
\text { Morskie }^{\mathrm{xx}}\end{array}$ & 32 & 3441 & 11. & Mielno & 32 & 1380,1 \\
\hline 12. & Ostrów ${ }^{\mathrm{xxx}}$ & 18 & 3267 & 12. & $\begin{array}{l}\text { Sitkówka- } \\
\text { Nowiny }\end{array}$ & 26 & 1300,1 \\
\hline 13. & $\begin{array}{l}\text { Sitkówka- } \\
\text { Nowiny }^{\mathrm{xx}}\end{array}$ & 26 & 3208 & 13. & Stepnica & 32 & 1292,2 \\
\hline 14. & Jerzmanowa $^{\mathrm{xx}}$ & 02 & 3062 & 14. & $\begin{array}{l}\text { Tarnowo } \\
\text { Podgórne }\end{array}$ & 30 & 1254,4 \\
\hline 15. & Bojszowy $^{\mathrm{xx}}$ & 24 & 3003 & 15. & $\begin{array}{l}\text { Ustronie } \\
\text { Morskie }\end{array}$ & 32 & 1231,5 \\
\hline 16. & Lomianki $^{\mathrm{xx}}$ & 14 & 2965 & 16. & Kobylanka & 32 & 1211,2 \\
\hline 17. & $\begin{array}{l}\text { Warszawa- } \\
\text { Białołęka }^{\text {xxx }}\end{array}$ & 14 & 2927 & 17. & Tymbark & 12 & 1209,1 \\
\hline 18. & Lubin gm. ${ }^{\mathrm{xx}}$ & 02 & 2909 & 18. & Ostrów & 18 & 1129,0 \\
\hline 19. & Kleczew $^{\mathrm{xx}}$ & 30 & 2723 & 19. & Łubnice & 26 & 1073,9 \\
\hline 20. & Lubniewice $^{\mathrm{xx}}$ & 08 & 2721 & 20. & $\begin{array}{l}\text { Goczałkowice- } \\
\text {-Zdrój }\end{array}$ & 24 & 1066,5 \\
\hline 21. & Kobylanka $^{\mathrm{xx}}$ & 32 & 2559 & 21. & Kleszczewo & 30 & 1018,8 \\
\hline 22. & Międzyzdroje $^{\mathrm{xx}}$ & 32 & 2525 & 22. & Krupski Młyn & 24 & 1018,5 \\
\hline 23. & Stare Babice ${ }^{\mathrm{xx}}$ & 14 & 2467 & 23. & Kostrzyn & 08 & 1006,2 \\
\hline 24. & Ornontowice $^{\mathrm{xx}}$ & 24 & 2372 & 24. & Stare Babice & 14 & 987,2 \\
\hline 25. & Jastarnia $^{\mathrm{xx}}$ & 22 & 2343 & 25. & Lubniewice & 08 & 979,3 \\
\hline 26. & Białowieża $^{\mathrm{xx}}$ & 20 & 2303 & 26. & $\begin{array}{l}\text { Kamieniec } \\
\text { Ząbkowicki }\end{array}$ & 02 & 972,1 \\
\hline 27. & Dziwnów $^{\mathrm{xx}}$ & 32 & 2264 & 27. & Piechowice & 02 & 955,2 \\
\hline 28. & Rudna $^{\mathrm{xx}}$ & 02 & 2256 & 28. & Jastarnia & 22 & 953,0 \\
\hline 29. & Stawiguda ${ }^{\mathrm{xxx}}$ & 28 & 2166 & 29. & Lubin & 02 & 931,7 \\
\hline 30. & $\begin{array}{l}\text { Kamieniec } \\
\text { Ząbkowicki }^{\mathrm{xx}}\end{array}$ & 02 & 2156 & 30. & Kobierzyce & 02 & 927,5 \\
\hline 31. & Lewin Kłodzki ${ }^{\mathrm{xx}}$ & 02 & 2141 & 31. & Kosakowo & 22 & 916,0 \\
\hline 32. & Michałowice $^{\mathrm{xx}}$ & 14 & 2140 & 32. & Rokietnica & 30 & 910,4 \\
\hline 33. & Krupski Młyn $^{\mathrm{xx}}$ & 24 & 2133 & 33. & Kleczew & 30 & 910,0 \\
\hline 34. & Kosakowo $^{\mathrm{xx}}$ & 22 & 2122 & 34. & Wisła & 24 & 908,3 \\
\hline 35. & $\begin{array}{l}\text { Kazimierz } \\
\text { Biskupi }^{\mathrm{xx}} \\
\end{array}$ & 30 & 2109 & 35. & Jerzmanowa & 02 & 902,7 \\
\hline 36. & $\operatorname{Kostrzyn}^{\mathrm{xx}}$ & 08 & 2109 & 36. & Sejny & 20 & 893,5 \\
\hline 37. & Piechowice $^{\mathrm{xx}}$ & 02 & 2074 & 37. & Łękawica & 24 & 887,5 \\
\hline 38. & $\begin{array}{l}\text { Borne } \\
\text { Sulinowo }^{\mathrm{xx}} \\
\end{array}$ & 32 & 2041 & 38. & $\begin{array}{l}\text { Warszawa- } \\
\text { Białołęka }\end{array}$ & 14 & 885,1 \\
\hline 39. & Sejny ${ }^{\mathrm{xx}}$ & 20 & 2020 & 39. & Brzeg Dolny & 02 & 873,4 \\
\hline
\end{tabular}




\begin{tabular}{|c|c|c|c|c|c|c|c|}
\hline 40. & Słupno $^{\mathrm{xxx}}$ & 14 & 2011 & 40. & Boronów & 24 & 836,6 \\
\hline 41. & Łagiewniki $^{\mathrm{xx}}$ & 02 & 1998 & 41. & Ostrówek & 10 & 835,1 \\
\hline 42. & Studzienice ${ }^{\mathrm{xx}}$ & 22 & 1954 & 42. & Rudka & 20 & 834,2 \\
\hline 43. & Mszczonów $^{\mathrm{xxx}}$ & 14 & 1949 & 43. & Dziwnów & 32 & 818,4 \\
\hline 44. & \begin{tabular}{|l|} 
Warta \\
Bolesławiecka
\end{tabular} & 02 & 1934 & 44. & Ornonotowice & 24 & 792,2 \\
\hline 45. & Kurnik $^{\mathrm{xx}}$ & 30 & 1925 & 45. & Rudna & 02 & 781,2 \\
\hline 46. & \begin{tabular}{|l} 
Polanica \\
Zdrój
\end{tabular} & 02 & 1921 & 46. & Michałowice & 14 & 775,6 \\
\hline 47. & Mszana $^{\mathrm{xx}}$ & 24 & 1913 & 47. & Słońsk & 14 & 770,9 \\
\hline 48. & $\begin{array}{l}\text { Garbatka- } \\
\text { Letnisko }^{\text {xx }}\end{array}$ & 14 & 1884 & 48. & Kłodzko & 02 & 770,1 \\
\hline 49. & Lesznowola $^{\mathrm{xx}}$ & 14 & 1879 & 49. & Podkowa Leśna & 14 & 766,4 \\
\hline 50. & Osiecznica ${ }^{\mathrm{xx}}$ & 02 & 1877 & 50. & Popielów & 16 & 765,2 \\
\hline
\end{tabular}

${ }^{\mathrm{xx}}$ - po raz drugi; ${ }^{\mathrm{xxx}}$ - po raz trzeci w pierwszej setce

Jeżeli zbadać dokładniej, jak się układają w polskiej przestrzeni wskaźniki tempa wzrostu, to okaże się, że nasza prowincja ma spory potencjał rozwojowy. Największy przyrost nowych firm nie występuje bowiem tam, gdzie jest ich najwięcej, czyli w wielkich miastach, ale właśnie na prowincji. W przeliczeniu na 1 mieszkańca jest tu ich relatywnie mniej niż w małych ośrodkach osadniczych.

Lokalne tempo rozwoju nowych firm wyjaśniają dwa podstawowe czynniki: poziom inwestycji samorządowych i liczba organizacji "non profit".

Oba przedstawione rankingi: atrakcyjności inwestycyjnej miast oraz liderów lokalnego rozwoju przyjęte zostały jako czynniki korygujące w prowadzonych badaniach.

W tabeli 5 przedstawiono porównanie pięćdziesięciu gmin o największych inwestycjach - według Centrum Badań Regionalnych oraz według materiałów analizowanych w prezentowanej pracy. Dane uzyskane z rankingu opracowanego przez Centrum dla lat 1997-1999 są istotne ze względu na pewną dynamikę omawianych zjawisk. Oba zestawienia pokazane

w tabeli są w wielu przypadkach porównywalne, mimo szerszego w pierwszym, i węższego w drugim przypadku zakresu czasowego. Dziwić może jedynie całkowite pominięcie w rankingu Centrum Badań Regionalnych tak pewnego - jak można przypuszczać na podstawie dotychczasowych analiz - lidera w skali Polski, jakim jest gmina Kleszczów.

Niestety, oba cytowane rankingi - CBR i IBnGR - ze względu na zakres niniejszej pracy są ograniczone ilościowo i nie obejmują wszystkich 2489 gmin występujących w kraju. Pierwszy z nich dotyczy wyłącznie miast, a drugi 100 najlepszych pod względem inwestycyjnym gmin.

\section{WYNIKI KOŃCOWE}




\section{Regionalne ogniska wzrostu (na podstawie współczynnika syntetycznego - bezwzględnego)}

Na terenie Polski znajdują się 42 ogniska regionalne i 31 potencjalnych. Nie wymagają one dodatkowych potwierdzeń, bowiem ich znaczenie jest oczywiste. W niniejszej pracy porównano je z wynikami rankingów IBnGR. Pod względem wartości współczynnika bezwzględnego $(>1,5)$ występują pomiędzy poszczególnymi ogniskami bardzo duże różnice. Od klasy najwyższej $(>20,0)$ do klasy niskiej $(3,0-5,0)$ są to wartości "4-wariantowe",

a więc istotne dla wszystkich stosowanych w badaniach ujęć analitycznych. Jedynie w najniższej klasie $(1,5-3,0)$ występuje 10 słabych ognisk wzrostu o wartościach tylko dla jednego lub dwóch wariantów. Całkowicie dominuje nad pozostałymi wielkimi miastami stolica Polski, a ściślej biorąc gmina Warszawa-Centrum. Średnia wartość współczynnika bezwzględnego (dla wszystkich 4 wariantów) wynosi dla Centrum 26,670, podczas gdy dla drugiego w kolejności Wrocławia - 13,644. Następny Poznań ma średnią wartość 12,536, Łódź - 12,509, Kraków - 10,972 .... aż do Koszalina o wartości 1,629. Jak z tego wynika rozpiętości pomiędzy poszczególnymi miastami są ogromne!

W strukturze regionalnych ognisk wzrostu występuje wyraźny układ hierarchiczny, z czym wiąże się zakres świadczonych usług na rzecz rozwoju przedsiębiorczości o charakterze pośrednim (np. uczelnie) i bezpośrednim (np. KSU czy EURO INFO). Usługi te mają również strukturę hierarchiczną - zbyt słabo może uwypukloną w niniejszej pracy. $\mathrm{Na}$ przeszkodzie stanął bowiem ogrom materiału analitycznego.

Tabela 6. Klasy regionalnych ognisk wzrostu - według liczby gmin

\begin{tabular}{|c|c|c|c|c|c|c|c|c|}
\hline \multirow{3}{*}{ Lp. } & \multirow{3}{*}{ Województwa } & \multicolumn{6}{|c|}{ REGIONALNE OGNISKA - I KLASA } & \multirow{3}{*}{$\begin{array}{c}\text { Ogniska } \\
\text { potencjalne } \\
- \text { II klasa } \\
1,0-1,5\end{array}$} \\
\hline & & \multirow{2}{*}{ Razem } & \multicolumn{5}{|c|}{$\begin{array}{c}\text { Wartości współczynnika syntetycznego } \\
\text { - bezwzględnego }\end{array}$} & \\
\hline & & & $>20,0$ & $10,0-20,0$ & $5,0-10,0$ & $3,0-5,0$ & $1,5-3,0$ & \\
\hline 1. & dolnośląskie & 4 & - & 1 & - & - & 3 & 2 \\
\hline 2. & kujawsko-pomorskie & 3 & - & - & 1 & 1 & 1 & - \\
\hline 3. & lubelskie & 1 & - & - & - & 1 & - & 4 \\
\hline 4. & lubuskie & 2 & - & - & - & - & 2 & 1 \\
\hline 5. & łódzkie & 1 & - & 1 & - & - & - & 3 \\
\hline 6. & małopolskie & 2 & - & 1 & - & - & 1 & 1 \\
\hline 7. & mazowieckie & 6 & 1 & - & - & - & 5 & 3 \\
\hline 8. & opolskie & 1 & - & - & - & 1 & - & - \\
\hline 9. & podkarpackie & 1 & - & - & - & 1 & - & 6 \\
\hline 10. & podlaskie & 1 & - & - & - & 1 & - & 2 \\
\hline 11. & pomorskie & 2 & - & - & 1 & 1 & - & 5 \\
\hline 12. & śląskie & 11 & - & - & 1 & 1 & 9 & - \\
\hline 13. & świętokrzyskie & 1 & - & - & - & 1 & - & 1 \\
\hline 14. & warmińsko-mazurskie & 2 & - & - & - & - & 2 & - \\
\hline 15. & wielkopolskie & 2 & - & 1 & - & - & 1 & 3 \\
\hline 16. & zachodniopomorskie & 2 & - & - & 1 & - & 1 & - \\
\hline 17. & ogółem & 42 & 1 & 4 & 4 & 8 & 25 & 31 \\
\hline
\end{tabular}


Lokalne bieguny wzrostu nie posiadają na swym terenie tego rodzaju usług poza spotykanymi w niektórych miejscach towarzystwami rozwoju określonej gminy. Usługi grupują się w miastach. Występuje tutaj pewna prawidłowość - im dany ośrodek określony jest przez wyższe wartości współczynnika syntetycznego, tym na jego terenie występuje szerszy wachlarz placówek wspomagania przedsiębiorczości. Są jednak dwa wyjątki: mało aktywne Katowice - ze względu na fakt, że szereg funkcji usługowych przejęły inne miasta Górnośląskiego Okręgu Przemysłowego, oraz pasywne w tej dziedzinie Opole. Samo pojęcie ogniska regionalnego wskazuje, że aktywizacja gospodarcza odbywa się poprzez większe miasta, które transmitują $\mathrm{w}$ otaczający teren impulsy innowacyjne. Z tego punktu widzenia J.R. Boudeville (1978) miał w pewnym stopniu rację usiłując połączyć "koncepcję polaryzacji” z "teorią ośrodków centralnych" W. Christallera. Zamiast proponowanych przez niego biegunów: wzrostu, rozwoju i integracji, wprowadzone zostały regionalne ogniska wzrostu - klasy I (faktycznie istniejące) i klasy II (potencjalne ogniska). Same bieguny lokalne nie wykazują bowiem istotnych cech hierarchicznych, różnią się między sobą spełnianymi funkcjami gospodarczymi, a w mniejszym stopniu wartościami współczynnika syntetycznego - względnego. Istnieją co prawda swoiste "kominy" tych wartości (np. Kleszczów), ale są to zjawiska sporadyczne. Można więc stwierdzić, że bieguny lokalne nie tworzą układów hierarchicznych, podczas gdy regionalne ogniska wzrostu - tak!

Jak wskazuje tabela 6 , układ ten jest następujący:

(1) klasa najwyższa $(>20,0)$, do której należy tylko jedno miasto Warszawa, a ściślej biorąc gmina Centrum. Dołączenie do niej pozostałych gmin warszawskich tylko w niewielkim stopniu może obniżyć wartość powyższego współczynnika. Wbrew swej nazwie ognisko to ma charakter w większym stopniu krajowy niż regionalny;

(2) klasa wysoka (10,0-20,0), obejmująca następujące miasta: Wrocław, Poznań, Łódź i Kraków. Pełnią one funkcje nie tylko regionalne, ale i ponadregionalne, przekraczając granice swoich województw;

(3) klasa średnia $(5,0-10,0)$, do której można zaliczyć: Bydgoszcz, Gdańsk, Katowice i Szczecin. Mają one charakter regionalny - oczywiście tylko w świetle przyjętych założeń niniejszej pracy. Miasta portowe oraz stolica Górnego Śląska pełnią bowiem szereg funkcji krajowych

i międzynarodowych. Powstaje pytanie, czy dołączenie do Katowic miast tworzących aglomerację katowicką i obliczenie dla nich wspólnych wartości współczynnika bezwzględnego zmieni powyższą hierarchię? Okazuje się, że tak! Średnia z wartości 9 głównych miast powyższego zespołu osadniczego wynosi bowiem 2,908 (dla wszystkich 4 wariantów);

(4) klasa niższa $(3,0-5,0)$ obejmuje następujące miasta (według kolejności województw): Toruń, Lublin, Opole, Rzeszów, Białystok, Gdynia, Częstochowa, Kielce. Jako słabsze od poprzednich ognisk wzrostu, mają one charakter regionalny lub podregionalny, ograniczony do części województwa, na którym występują. Dziwić może zaliczenie do tej klasy Gdyni. Wyłączenie jej z aglomeracji gdańskiej (Trójmiasta) oraz ocena za pomocą wartości statystycznych opartych na budżetach gmin, przedsiębiorczości prywatnej i wspomaganiu tej przedsiębiorczości daje takie właśnie usytuowanie Gdyni w układzie hierarchicznym. Jej podstawowe funkcje są bowiem inne od analizowanych w niniejszej pracy. Słabo wypadają w prezentowanej klasyfikacji stolice tzw. ściany wschodniej, co potwierdza powszechną opinię o opóźnionej w rozwoju Polsce "B";

(5) klasa najniższa $(1,5-3,0)$ regionalnych ognisk wzrostu obejmuje 25 miast mających charakter uzupełniający w zakresie aktywizacji gospodarczej. Są to: Wałbrzych, Jele- 
nia Góra, Zgorzelec, Włocławek, Gorzów Wielkopolski, Zielona Góra, Radom, Płock, 3 administracyjnie wydzielone gminy Warszawy (Ursynów, Bielany, Włochy), Bielsko-Biała, 8 miast aglomeracji katowickiej (Gliwice, Sosnowiec, Zabrze, Bytom, Tychy, Rybnik, Dąbrowa Górnicza i Chorzów), Tarnów, Olsztyn, Elbląg, Kalisz i Koszalin. W grupie tej dominują stolice dawnych "małych" województw oraz 3 aktualne ośrodki wojewódzkie. Ciekawym przypadkiem badawczym jest Lubuskie, gdzie oddolna - jak można przypuszczać - aktywność gmin, z których część zaliczona została do lokalnych biegunów wzrostu, nie idzie w parze z przedsiębiorczością w skali wojewódzkiej.

Do klasy ognisk potencjalnych należy 31 jednostek. Występują one głównie w tych regionach, w których ośrodki wojewódzkie są słabe lub mają niedostateczne wsparcie w uzupełniających ogniskach wzrostu.

\section{Lokalne bieguny wzrostu}

Pierwsza weryfikacja przeprowadzona w niniejszej pracy polegała na sprawdzeniu uzyskanych wyników w nawiązaniu do istniejącej literatury przedmiotu. Założono, że liczba wytypowanych biegunów lokalnych może być zbyt mała ze względu na restrykcyjny charakter zastosowanych metod analizy. Innymi słowy zachodziła obawa, że niektóre z aktywnych gospodarczo gmin mogły nie zostać zakwalifikowane do powyższej grupy. Syntetyczny współczynnik względny obcinał bowiem wszystkie gminy $<1,5$ odchylenia od wzorca, a głównie były to jednostki administracyjne, gęsto zaludnione i liczące $>10,000$ mieszkańców. Takie było zadanie tego współczynnika, ale w ten sposób wyeliminowane zostały w większości gminy podwarszawskie. Pojawiły się one natomiast w zbliżonych tematycznie rankingach opracowanych przez IBnGR i CBR. Z tego względu pod presją wyników uzyskanych w innych badaniach uchylono "furtkę", wpuszczając niektóre gminy (o wartościach 1,0-1,5) do grona lokalnych biegunów wzrostu. W ten sposób z początkowej wielkości 111 jednostek ich liczba wzrosła do 154 w całym kraju. Na tym uzupełnianiu biegunów najbardziej skorzystało województwo mazowieckie, które wzbogaciło się o 12 dodatkowych, wyróżnionych jednostek samorządowych. W ujęciu przestrzennym okazało się, że są to wyłącznie gminy podwarszawskie, a ściślej biorąc należące do aglomeracji stołecznej. W związku z tym powstało pytanie, czy przeprowadzony manewr był słuszny? Gminy żyjące w cieniu wielkiego sąsiada (np. Warszawy), rozwijając się przejmują szereg jego funkcji i stają się kolejną dzielnicą dużego miasta. $Z$ tego względu mówienie o nich jako

o lokalnych biegunach wzrostu traci sens.

Tabela 6. Liczba lokalnych biegunów wzrostu - wyniki końcowe

\begin{tabular}{|c|c|c|c|c|c|}
\hline $\begin{array}{c}\text { Kolej- } \\
\text { ność }\end{array}$ & $\begin{array}{c}\text { Wojewódz- } \\
\text { twa }\end{array}$ & $\begin{array}{c}\text { Liczba } \\
\text { po- }\end{array}$ & I weryfikacja & II weryfikacja & $\begin{array}{c}\text { Udział biegunów w ogólnej } \\
\text { liczbie gmin }\end{array}$ \\
\hline
\end{tabular}




\begin{tabular}{|c|l|c|c|c|c|c|c|c|c|}
\hline & & $\begin{array}{c}\text { cząt- } \\
\text { kowa } \\
\text { bie- } \\
\text { gunów }\end{array}$ & $\begin{array}{c}\text { uzupeł- } \\
\text { nianie } \\
\text { biegunów }\end{array}$ & razem & $\begin{array}{c}\text { eliminacja } \\
\text { biegunów }\end{array}$ & razem & $\begin{array}{c}\text { liczba } \\
\text { gmin } \\
\text { (ogó- } \\
\text { łem) }\end{array}$ & $\begin{array}{c}\text { w tym } \\
\text { bieguny } \\
(\%)\end{array}$ & $\begin{array}{c}\text { kolejność } \\
\text { wg udzia- } \\
\text { łu } \\
(\%)\end{array}$ \\
\hline 1. & $\begin{array}{l}\text { zachodnio- } \\
\text { pomorskie }\end{array}$ & 16 & +3 & 19 & -2 & $\mathbf{1 7}$ & 114 & 14,9 & 2 \\
\hline 2. & lubuskie & 11 & +3 & 14 & - & $\mathbf{1 4}$ & 83 & 16,7 & 1 \\
\hline 3. & dolnośląskie & 13 & - & 13 & - & $\mathbf{1 3}$ & 169 & 7,7 & 4 \\
\hline 4. & pomorskie & 10 & +6 & 16 & -3 & $\mathbf{1 3}$ & 123 & 10,6 & 3 \\
\hline 5. & wielkopolskie & 11 & +2 & 13 & -2 & $\mathbf{1 1}$ & 226 & 4,9 & 8 \\
\hline 6. & lódzkie & 11 & +2 & 13 & -4 & $\mathbf{9}$ & 177 & 5,1 & 5 \\
\hline 7. & lubelskie & 8 & - & 8 & - & $\mathbf{8}$ & 213 & 3,7 & 10 \\
\hline 8. & podkarpackie & 5 & +3 & 8 & - & $\mathbf{8}$ & 160 & 5,0 & 7 \\
\hline 9. & mazowieckie & 7 & +12 & 19 & -13 & $\mathbf{6}$ & 325 & 1,8 & 15 \\
\hline 10. & podlaskie & 4 & +2 & 6 & - & $\mathbf{6}$ & 118 & 5,1 & 6 \\
\hline 11. & śląskie & 4 & +2 & 6 & -1 & $\mathbf{5}$ & 166 & 3,0 & 12 \\
\hline 12. & $\begin{array}{l}\text { kujawsko- } \\
\text {-pomorskie }\end{array}$ & 5 & - & 5 & - & $\mathbf{5}$ & 144 & 3,5 & 11 \\
\hline 13. & $\begin{array}{l}\text { warmińsko- } \\
\text {-mazurskie }\end{array}$ & 3 & +2 & 5 & - & $\mathbf{5}$ & 116 & 4,3 & 9 \\
\hline 14. & małopolskie & 1 & +5 & 6 & -1 & $\mathbf{5}$ & 182 & 2,7 & 14 \\
\hline 15. & $\begin{array}{l}\text { święto- } \\
\text { krzyskie }\end{array}$ & 2 & +1 & 3 & - & $\mathbf{3}$ & 102 & 2,9 & 13 \\
\hline 16. & opolskie & - & - & - & - & - & 71 & - & - \\
\hline 2 & ogółem & 111 & +43 & 154 & -26 & $\mathbf{1 2 8}$ & 2489 & 5,1 & 2 \\
\hline
\end{tabular}

Przeprowadzono więc drugą weryfikację wyników badawczych, posługując się wnioskami płynącymi z rzeczywistości. A wskazują one na fakt, że gminy podmiejskie są częścią większej całości i mogą być uważane za "bieguny rozwoju” według J.R. Boudeville’a (1978,

s. 53), ale czy za bieguny lokalne? Zgodnie z przyjętym na początku niniejszej pracy założeniem, pod pojęciem "lokalności” należy rozumieć zjawisko przestrzenne domykające się pod względem decyzyjnym i finansowym w skali miejscowej (lub lokalnej). Pojęcie to odnosi się do jednostek niewielkich, samodzielnych i aktywnych gospodarczo. Tych założeń nie spełniają w dostatecznym stopniu gminy - integralne części aglomeracji miejskich.

Tak więc II weryfikacja polegała na ich eliminacji z wybranej grupy lokalnych biegunów wzrostu. Jak wskazuje tabela 7, w wyniku przeprowadzonej redukcji największe straty (po chwilowym zysku) poniosło województwo mazowieckie, tracące 13 aktywnych gospodarczo gmin. Bez dodatkowych badań widać wyraźnie ich bezpośrednią łączność z Warszawą z którą tworzą jeden zespół osadniczy. W podobny sposób wyeliminowane zostały 4 gminy (bieguny) wchodzące w skład aglomeracji łódzkiej, 3 gminy, które odniesiono do układu Trójmiasta, po 2 jednostki administracyjne zaliczone do zespołu szczecińskiego i poznańskiego oraz po 1 gminie aglomeracji krakowskiej i katowickiej. W wyniku przeprowadzenia II weryfikacji z ogólnej liczby 154 biegunów ubyło w ten sposób 26 jednostek. Tak więc na terenie Polski stwierdzono ostatecznie istnienie 128 lokalnych biegunów wzrostu, co stanowi 5,1\% wszystkich gmin w kraju. Według tabeli 7 na pierwszym miejscu znajduja się wśród województw zachodniopomorskie z 17 jednostkami, następnie lubuskie z 14 i dolnośląskie z 13 jednostkami. Dominuje w tej dziedzinie "zachodnia ściana" Polski. Po dołączeniu kolejnych dwóch województw: pomor- 
skiego i wielkopolskiego, łączna liczba biegunów wynosi 68, tj. 53\% wszystkich znajdujących się na terenie kraju. Jednakże województwa są różnej wielkości, a nie ma większego sensu przeliczanie liczby biegunów na $1 \mathrm{~km}^{2}$ lub na $100 \mathrm{~km}^{2}$. Odniesienie do liczby mieszkańców zawiera już w sobie syntetyczny współczynnik względny. Można jednak obliczyć udział biegunów w ogólnej liczbie gmin danego województwa. Na pierwsze miejsce w Polsce wysuwa się województwo lubuskie, gdzie bieguny lokalne stanowią 16,7\% wszystkich tamtejszych gmin. Dopiero na drugim miejscu plasuje się zachodniopomorskie $(14,9 \%)$, na trzecim pomorskie $(10,6 \%)$ i na czwartym dolnośląskie $(7,7 \%)$. Jak z powyższego wynika, dominujące województwa pozostały, zmieniła się jedynie ich kolejność. O ile poprzednio na ostatnim miejscu pod względem liczby biegunów znajdowało się województwo świętokrzyskie (nie licząc opolskiego, gdzie biegunów nie było), to obecnie miejsce to zajęło woj. mazowieckie. W tym największym w kraju województwie, podzielonym na 325 gmin, tylko 1,8\% z nich uznana została za lokalne bieguny wzrostu.

\section{PODSUMOWANIE}

W skali Polski wyróżnić można dwa odmienne, ale i współzależne układy.

1. Układ równorzędności wykazuje słaby stopień wewnętrznej integracji, polegającej na sprzęganiu kilku (lub więcej) podukładów lub układów niższego rzędu w jeden ogólny system. Z reguły zapewnia to jego większą efektywność w stosunku do niesprzężonego szeregu podsystemów składowych. Lokalne bieguny wzrostu nie tworzą jakiegoś układu scalonego w większej skali. Jeżeli pojawiają się powiązania pomiędzy poszczególnymi jednostkami samorządowymi, to występują one ze względu na jakiś element wspólny: atrakcyjne położenie geograficzne, rozmieszczenie surowców, bliskość zachodniej granicy itp. Poza tym, zgodnie z "teorią polaryzacji”, biegunem wzrostu jest z reguły aktywny gospodarczo ośrodek (np. kuracyjny, przemysłowy, handlowy), z którego emanują siły dośrodkowe

i odśrodkowe, powodujące wykształcenie się sfery gospodarczej, będącej obszarem jego działania (Perroux 1955, s. 309). W pierwszym rzędzie tym obszarem jest własna gmina, która stanowi nie tylko zbiór jednostek gospodarczych, ośrodek decyzyjny, ale i społeczno-kulturowy. Kilka lub więcej gmin może tworzyć na zasadzie partnerstwa układ o funkcjach równorzędności, bazujący na jakiejś wspólnej i atrakcyjnej gospodarczo dziedzinie. Na przykładzie Kleszczowa i sąsiednich gmin widać jak - dzięki zyskom uzyskiwanym z kopalni i elektrowni - rozbudowana jest infrastruktura lokalna, następnie ściagają inwestorzy (coraz bardziej niezależni od bazowego źródła aktywizacji), wreszcie powstają usługi,

w tym wspomagania przedsiębiorczości. Dalszym etapem rozwoju będzie łączenie się zatomizowanych jednostek samorządowych w różne nieformalne i formalne związki. Według pozarządowej organizacji "KLON - JAWOR" działają one na rzecz rozwoju: konkretnej ziemi (z reguły powiatu), swojego miasta lub gminy wiejskiej oraz związku kilku jednostek, mających na uwadze realizację jakiegoś celu. Stowarzyszenia, fundacje i towarzystwa mają swoje siedziby w gminach, pełniących z reguły centralną rolę w najbliższym 
otoczeniu. Najczęściej placówki te - powoływane oddolnie - powstają w tych ośrodkach, które są gospodarczo dobrze rozwinięte lub mają kultywowaną tradycję historyczną. W koncepcji polaryzacji podkreśla się rolę różnorodnych rodzajów powiązań, które w tego rodzaju układach odgrywają istotną rolę. Łączą one liczne niewielkie firmy w jedno skupienie ulegające jednak ciągłej transformacji. W Polsce "klastery", które gdzieniegdzie powstały, nie mają istotnego znaczenia i polegają na formalnym naśladowaniu zachodnich wzorców. Na podstawie kilkunastu takich skupisk trudno wyciągać jakieś ogólne wnioski. Współpraca

w skali lokalnej zaczyna się w zasadzie na szczeblu gminnym i to gminy stały się podstawowym obiektem prowadzonych badań. We współpracy tej istotną rolę odgrywa bliskość geograficzna działających wspólnie jednostek. Wiele gmin nie korzysta z usług świadczonych na wyższych szczeblach hierarchii osadniczej. Radzą sobie samodzielnie (np. w woj. lubuskim), nawiązują kontakty, korzystając z zachodnich wzorów i pomocy finansowej.

W związku z tym bardziej trafne byłoby przyjęcie w pracy pojęcia gminnych biegunów wzrostu lokalnego. W Polsce wyróżnić można następujące typy tych biegunów:

- gminy mocno uprzemysłowione, gdzie w pobliżu zakładów przemysłu ciężkiego lokalizują się małe i średnie firmy prywatne korzystające $\mathrm{z}$ istniejącej infrastruktury technicznej, dogodnego rynku pracy itd.;

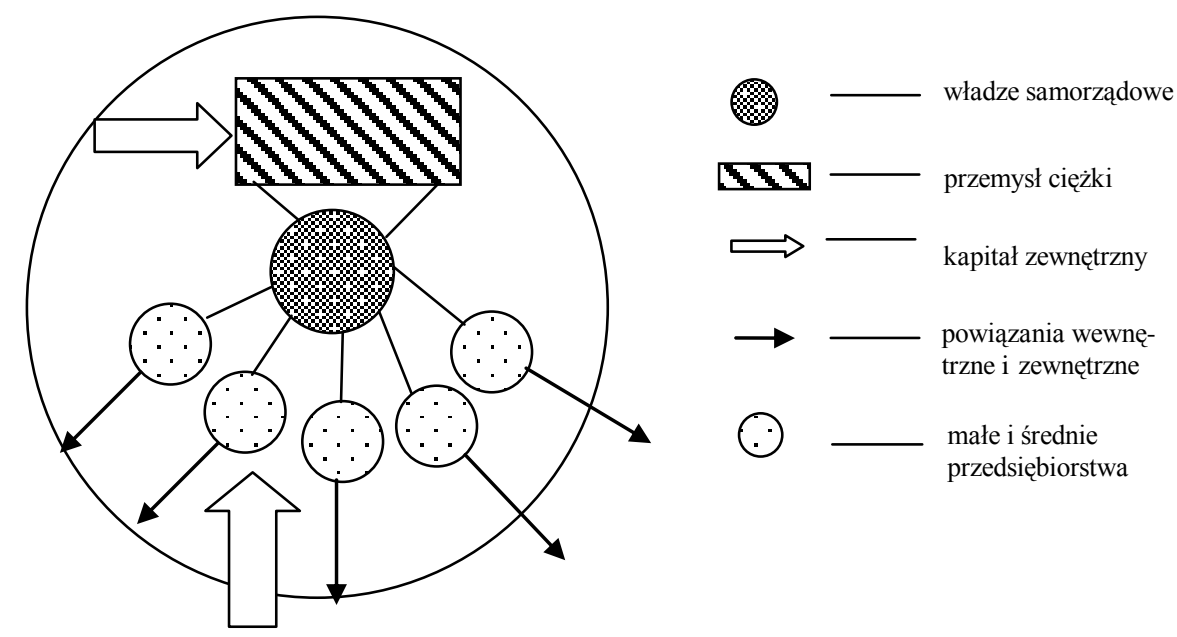

- gminy, w obrębie (lub w pobliżu) których zlokalizowane są wielkie bazary przygraniczne nastawione na handel z Niemcami;

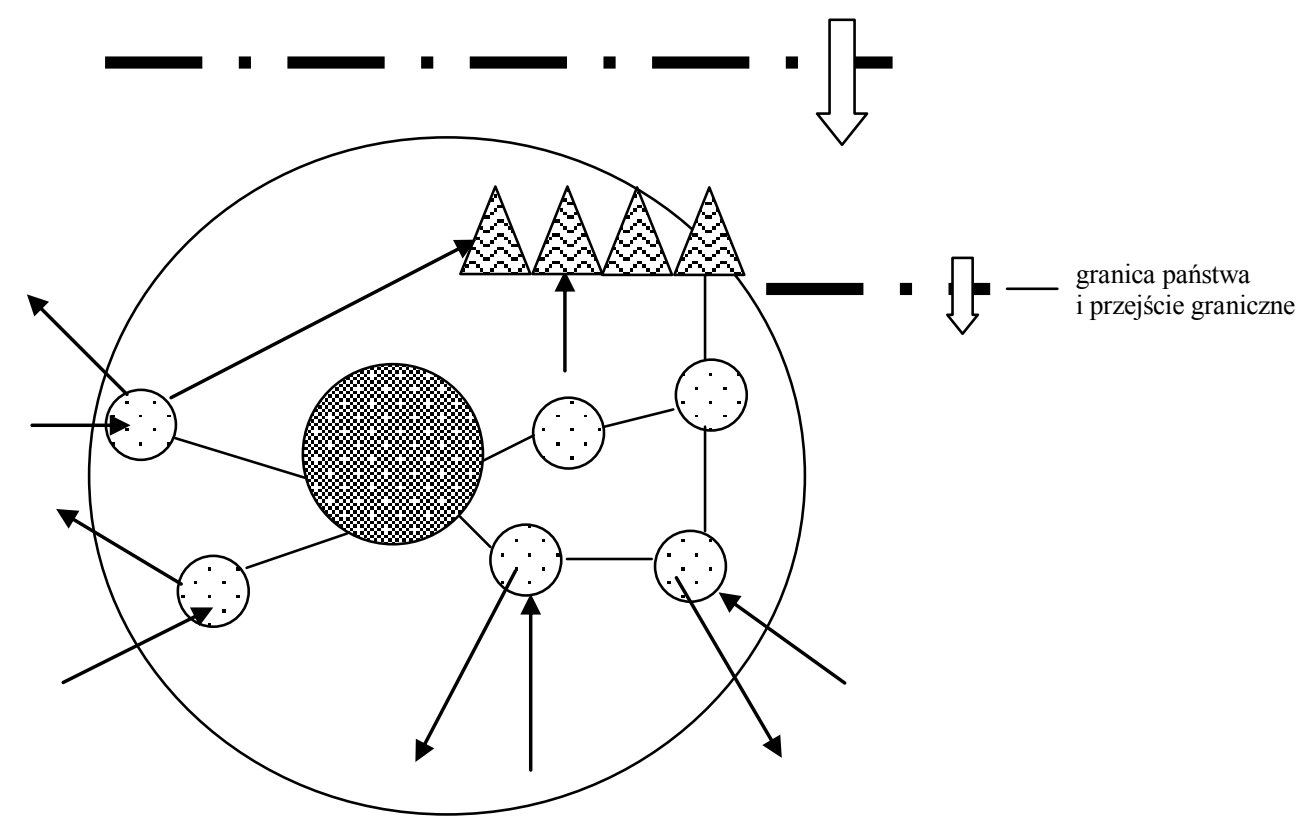




\section{会A - wiekli bazar}

- gminy, na terenie których znajdują się znane kurorty (nadmorskie, w mniejszym stopniu podgórskie) położone w bliskim sąsiedztwie granicy;

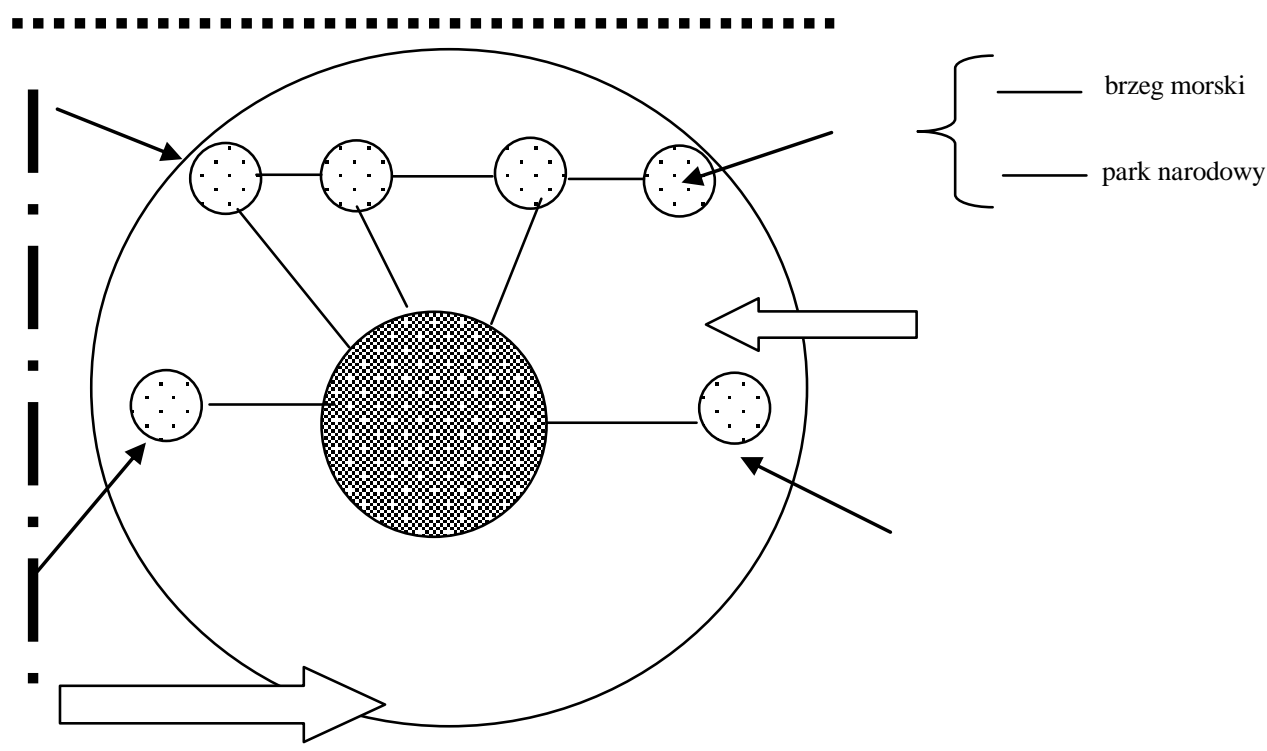

- gminy rozproszone przestrzennie, osiaggające wysokie dochody w wyniku dobrej gospodarki władz samorządowych popierających rozwój małej i średniej przedsiębiorczości oraz właściwie wykorzystujących fundusze wspierające;

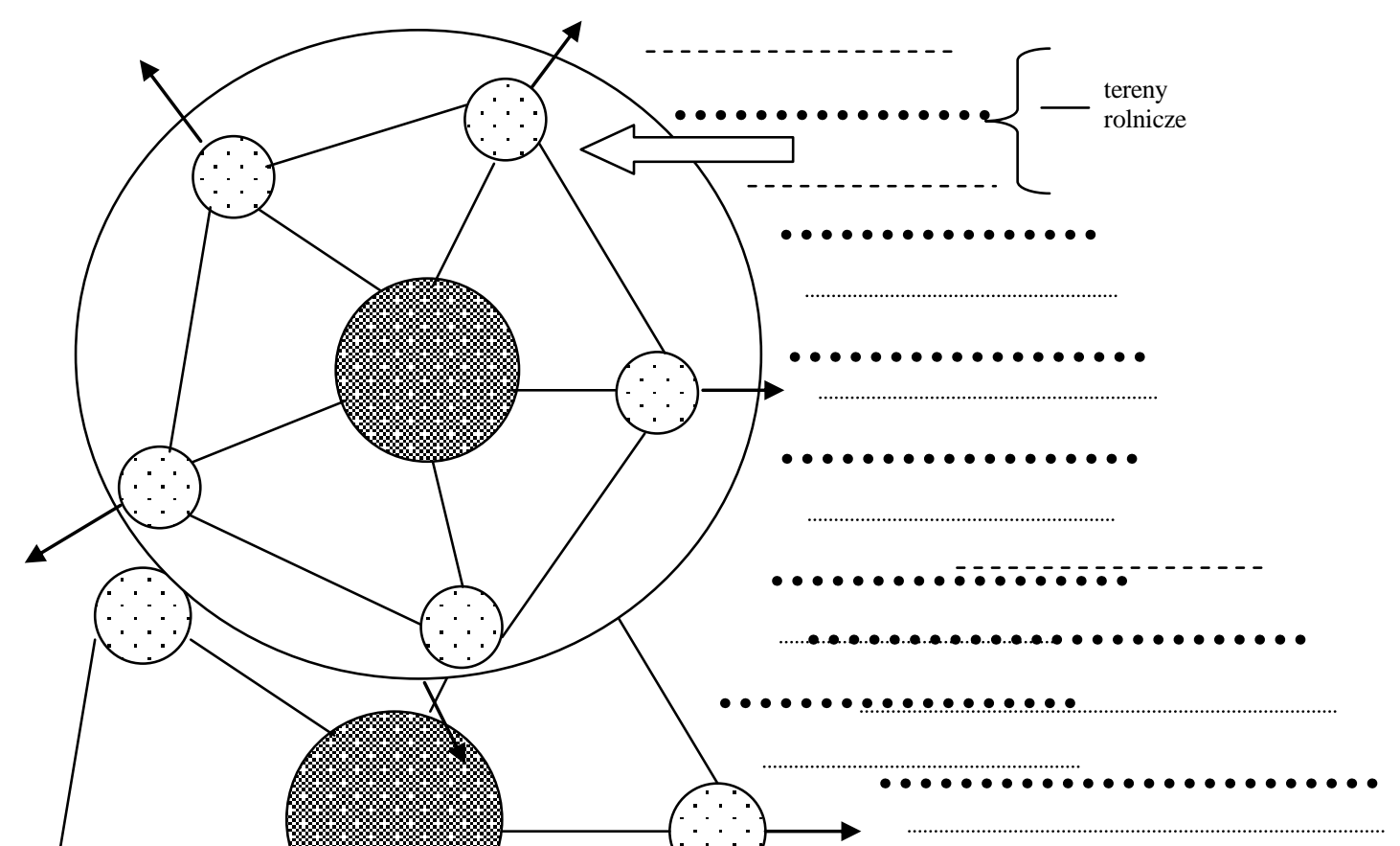


- gminy tworzące aktywnie gospodarczo układy sąsiedzkie, graniczące ze sobą i korzystające wspólnie z lokalnych surowców (i innych walorów środowiskowych), dogodnego położenia, rozwiniętej infrastruktury, zasobów siły roboczej itd.

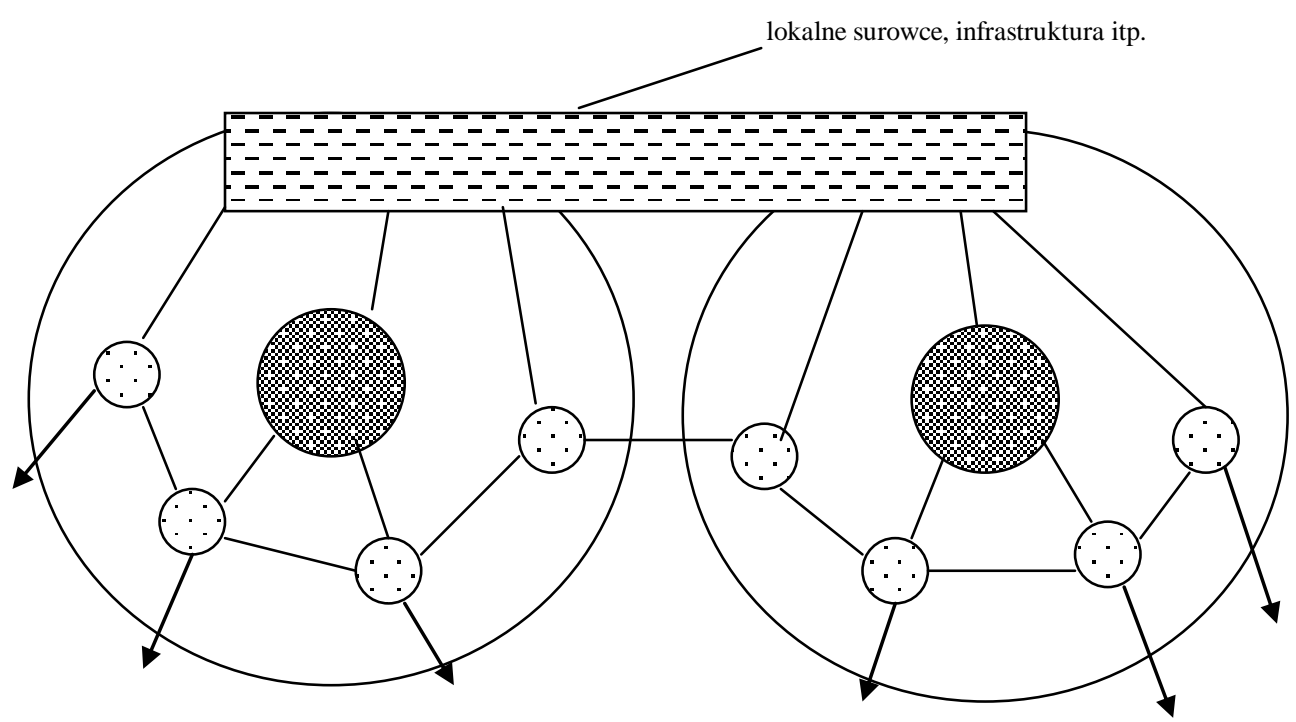

\section{Układ podporządkowania}

Regionalne ogniska wzrostu mają układ hierarchiczny o funkcjach podporządkowania w stosunku do ośrodka wyższego. Na terenie Polski występują:

- ognisko centralne - stolica, o najwyższych wartościach syntetycznego współczynnika bezwzględnego, dysponująca pełnym wachlarzem usług centralnych wspomagania przedsiębiorczości;

- ogniska ponadregionalne - o wysokich wartościach powyższego współczynnika i o licznych usługach o charakterze rynkowym i pozarynkowym, których oddziaływanie przekracza zasięg własnego województwa. Uczelnie, parki technologiczne, inkubatory przedsiębiorczości oraz placówki wspomagania inicjatywy prywatnej określają pozycję hierarchiczną powyższych ognisk; 
- ogniska regionalne - o funkcjach regionalnych i funkcjach wyspecjalizowanych w zakresie związanym z charakterem gospodarczym województwa. Wachlarz usług występujących na ich terenie jest węższy niż poprzednio, ale bardziej specyficzny (mniej uniwersalny), związany z określoną produkcją lub usługami;

- ogniska podregionalne - na terenach lepiej gospodarczo rozwiniętych mają charakter uzupełniający w stosunku do stolic województw. Dysponują mniejszym od nich wachlarzem usług. Na terenie Polski północno-wschodniej i wschodniej na poziomie ognisk podregionalnych znajdują się miasta wojewódzkie;

- ogniska ponadlokalne - stanowią ogniska pośrednie między ogniskami regionalnymi a biegunami lokalnymi. Należą do nich miasta na prawach powiatu lub ośrodki powiatowe wykazujące się pewną aktywnością gospodarczą odróżniającą je od innych jednostek o podobnej wielkości. W dwóch przypadkach do tej grupy należą stolice wojewódzkie o zakresie oddziaływania znacznie szerszym od ognisk ponadlokalnych.

Przedstawiona klasyfikacja nawiązuje pośrednio do teorii ośrodków centralnych W. Christallera (1933) oraz do jej modyfikacji przedstawionej przez A.K. Philbricka (1957). Ogranicza się jednak do 5 poziomów hierarchii, a nie do 7 i nie schodzi do samego dołu osadniczego układu hierarchicznego. Dwa dolne poziomy - w przeciwieństwie do obu powyższych prac - mają w niniejszym ujęciu charakter niehierarchiczny, tworząc układ równorzędności funkcji, którego podstawą jest samorząd lokalny.

\section{Literatura}

Boudeville J.-R., 1972, Aménagment du territorire et polarisation, Paris

Boudeville J.-R., 1978, Les règinos de villes et l'Europe, [w:] J. Paelinck, La structure urbaine en Europe Occidentale: faits, thèories, modèles, Westmead

Christaller W., 1933, Die Zentralen Orte in Suddeutschland, Jena

Gołembska E., 1990, Lokalny rynek zaopatrzenia i uslug, [w:] Rozwój gospodarki lokalnej w teorii i praktyce, Warszawa-Poznań

Grzeszczak J., 1999, Bieguny wzrostu a formy przestrzeni spolaryzowanej, "Prace Geograficzne" 16

Kukliński A., Polska lokalna i samorzad terytorialny w warunkach reformy, Warszawa

Paelinck J., 1965, La théorie développement régional polarisé, "Cahiers de I.d SEA", no 159, serie L, Paris

Perroux F., 1955, Note sur la nation de "pôle de eroisance", "Économic Apliquée", t. VIII, no 1-2

Philbrick A.K., 1957, Areal Functional Organization in Regional Geography, "Papers and Proceedings of the RSA", vol. 3

Swianiewicz P., Dziemianowicz W., 1999, Atrakcyjność inwestycyjna miast. II ranking, Warszawa 